\title{
Pilates Egzersizlerinin Beden Algısına Etkisi ${ }^{1}$
}

\author{
Hediye KÜÇÜKAPAN² \\ Adem CIVAN $^{3}$
}

\section{$\ddot{\mathbf{O} z}$}

$\mathrm{Bu}$ araştırmada 10 haftalık pilates egzersiz programının beden algısı üzerine etkisinin incelenmesi amaçlanmıştır.

Araştırmaya 52 kişi deney (yaş 32,62 $\pm 5,03$ yıl) ve 52 kişi kontrol grubu (yaş: $34,23 \pm 2,82$ yll) olmak üzere toplamda 104 sedanter kadın katılmıştır. Çalışma programında deney grubuna 10 hafta süresince; haftada 2 gün, 50 dakika pilates antrenmanı yaptırılmıştır. Araştırmaya katılan kadınların bedenlerini algılama düzeylerini belirlemek için Çok Yönlü Beden Benlik İlişkileri Ölçeği kullanılmıştır. Ölçekler ön test ve son test şeklinde her iki guruba da uygulanmıştır.

Araştırmaya katılan deney grubunun beden algısı ön test ve son test puanlarının karşılaştırılması sonucunda; görünüş değerlendirme, görünüş yönelimi, fiziksel yeterliliğin değerlendirilmesi, fiziksel yeterlilik yönelimi, sağlık değerlendirme, sağlık yönelimi, beden alanlarında doyum ve toplam puan açısından istatistiksel olarak anlamlı bir farklılık olduğu tespit edilmiştir $(\mathrm{p}<0,05)$. Kontrol grubunun beden algısı ön test ve son test puanlarının karşılaştırılması sonucunda ise görünüş yönelimi, fiziksel yeterliliğin değerlendirilmesi, fiziksel yeterlilik yönelimi ve toplam puan açısından istatistiksel olarak anlamlı bir farklılık olduğu tespit edilmiş̧ir $(\mathrm{p}<0,05)$. Buna karşın görünüş değerlendirme, sağlık değerlendirme, sağlık yönelimi, beden alanlarına doyum alt boyutlarında istatistiksel olarak anlamlı bir farklılık olmadığ tespit edilmiştir ( $p>0,05)$.

Sonuç olarak, pilates egzersizlerinin beden algısı üzerine olumlu etkisi olduğu ve pilates egzersizlerinin sedanter kadınların beden algılarını geliştirdiği söylenebilir.

Anahtar Kelimeler: Beden algis1, Egzersiz, Pilates

\section{Effect of Pilates Exercises on Body Image}

\begin{abstract}
In this study, it was aimed to examine the effect of 10 -week pilates exercise program on body image.

A total of 104 sedentary women were included in the study, including 52 experimental (mean age $32.62 \pm$ 5.03 ) and 52 control group (average of age: $34.23 \pm 2.82$ ). In the study program, the experimental group for 10 weeks; pilates training was done for 50 minutes a day, 2 days a week. Participants in the control group did not participate in any physical activity during 10 weeks The Multidimensional Body-Self Relations Questionnaire (MBSRQ) was used to determine the body perception level of the women participating in the study. The questionnaires were applied to both groups as pre-test and post-test.

As a result the comparison of the body perception pre-test and post-test scores of the experimental group participating in the study; It was determined that there is a statistically significant difference in terms of appearance assessment, appearance orientation, assessment of physical competence, physical competence orientation, health assessment, health orientation, satisfaction in body areas and total score ( $\mathrm{p}<0.05)$. In As a result the comparison of the body perception pre-test and post- test scores of the control group; it was determined that there is a statistically significant difference in terms of appearance orientation, assessment of physical competence, physical competence orientation and total score $(\mathrm{p}<0.05)$, on the other hand, no

\footnotetext{
${ }^{1} \mathrm{Bu}$ çalışma yüksek lisans tezinden özetlenmiştir.

2 Selçuk Üniversitesi, Spor Bilimleri Fakültesi, Konya-Türkiye.hediyek.apan@windowslive.com , https://orcid.org/0000-0002-5713-4769

3 Sorumlu Yazar; Selçuk Üniversitesi, Spor Bilimleri Fakültesi, Konya-Türkiye acivan@selcuk.edu.tr , https://orcid.org/0000-0002-4813-6471
} 
statistically significant difference was found in the sub- dimensions of appearance evaluation, health evaluation, health orientation, and body area satisfaction $(\mathrm{p}>0.05)$.

In conclusion, pilates exercises are thought to have a positive effect on body perception, and it can in conclession be said that pilates exercises improve body perception of sedentary women.

Keywords: Body Perception, Pilates, Exercise

\section{GíRiş}

Gelişen teknoloji insanların gündelik yaşantısını kolaylaştırıp yaşam kalitesini arttırıyor gibi görünse de hareketsizliği beraberinde getirmekte ve sedanter yaşam tarzının ortaya çıkmasına neden olmaktadır (Nieman 2007). Hareketsiz yaşam tarzı gün içerisinde harcanan enerji miktarının azalmasina ve bunun getirisi olarak vücut ağırlığında artış gibi fiziksel yönden olumsuz etkilere sebep olmaktadır (Uslu 2019, Şavkın 2014). Spor aktiviteleri, kişinin güçlü fiziksel fonksiyonlarını kontrol etme yeteneğine sahip olmasinda (Civan 2021) ve insanların bedensel algılarını pozitif olarak etkilemesinde önemli bir faktördür (Cusumano ve Thompson 1997).

Beden algıs1, kişinin kendi bedeninin diğer kişiler tarafından nasıl göründüğü konusundaki düşünceleri, davranışları ve duyguları olarak açıklanır (Akman 2019). Birçok farklı şekilde tanımlanan beden algısı kavramı tek bir yönde odaklanmaktadır; o da vücudun formu, biçimi ve ölçüsü gibi fiziksel maddelerini ve bu 11 özelliklerle alakalı hisleri barındıran, bilinçte meydana gelen çizim olarak tanımlanmıştır (Alagül 2004). Beden algısı başka bir tanımda ise iki adımda tabir edilmektedir. İlk adımda beden algısının bir değerlendirme olduğu ve bireyin fiziksel görünümü hakkındaki inanışını, fikirlerini incelemesi ve değerlendirmesini içermektedir. Beden algisının ikinci adımında beden algisı birikimi üstünde durulmaktadır yani kişinin bu adımda fiziken olmak istediği vücudu elde etmek için harekete geçtiği, çabaladığı ve performans sergilediği ferdi tavırlarıdır (Morrison ve ark 2004).

Günümüzde en çok tercih edilen egzersiz programlarindan biri olan ve Joseph $\mathrm{H}$. Pilates'in geliştirdiği pilates metodu fiziksel egzersizin kas ve kemik sağlığının yanı sıra kişilerin ruh sağlığı üzerinde de olumlu etkilerinin olduğunu göstermiştir. Pilates, zihin ve beden bütünlüğü ile birlikte denge, nefes ve hareket sistemlerinin ortaya çıkardığı disiplinlerden oluşan bir birleşimidir (CruzFerreira ve ark 2011).

Pilates egzersizi, Joseph Hubertus Pilates tarafından geliştirilmiş bir çeşit beden ve zihin merkezleme tekniğidir. $\mathrm{Bu}$ metoda kas kontrolü adını kurucusu Joseph Pilates vermiştir (Kloubec 2010). Pilates yönteminin amacı dolaşım, fiziksel uygunluk, esneklik, postural hizalama, vücut farkındalığ 1 ve motor koordinasyonun geliştirilmesi ve iyileştirilmesi esasına dayanır.

Literatürde farklı egzersiz türlerine ait beden algısına etkisini gösteren çalışmalar olduğu görülmektedir (Yararbaş 2013; Ergun 2017). Ancak pilates egzersizi yapan sedanter bayanlarda beden algisı değerlendiren sinırlı sayıda bilgi mevcuttur.

\section{Araştırmanın Amacı}

$\mathrm{Bu}$ çalışmada sedanter bayanlarda pilates egzersizlerinin beden algisı üzerine etkisini incelemek amaçlanmıştır.

\section{YÖNTEM}

\section{Örneklem/Çalışma Grubu/Katılımcılar}

$\mathrm{Bu}$ araştırma Konya ilinde I-fit Reformer Pilates stüdyosunda yapılmıştr. Çalışmaya yaş ortalamas1 $32,62 \pm 5,03$ sedanter 52 kadın deney grubu olarak, yaş ortalaması: $34,23 \pm 2,82$ sedanter 52 kadin ise kontrol grubu olarak toplam 104 denek katılmıştır.

\section{Veri Toplama Araçları/Veri Toplama Yöntemleri / Veri Toplama Teknikleri}

Kat1lımcilar deney ve kontrol grubu olmak üzere ikiye rastgele şekilde ayrılmıştır. Deney 
grubu pilates egzersiz programına katıld1, kontrol grubu herhangi bir egzersiz programına katılmamıştır. Katılımcılar araştırma öncesi bilgilendirilmiş ve imzalı onayları alınmıştır. Deneklere çalışmanın amac1 anlatılarak beden alg1 düzeylerini belirlemek için deney ve kontrol grubuna ön test 1992 yılında Doğan ve Doğan tarafindan geliştirilen, güvenilirliği ve geçerliliği sınanmış "Çok Yönlü Beden-Self İlişkisi Ölçeği (The Multidimensional Body-Self Relations Questionnaire- MBSRQ)" uygulanmıştır.

MBSRQ beden imajının davranışsal yönlerini değerlendirmek için geliştirilen ve 69 maddeden oluşan kişinin kendini değerlendirme ölçeğidir. Orijinali 1984 y1linda Winstead ve Cash tarafindan 140 maddeden oluşan bir ölçek olarak geliştirilmiş ve 54 maddelik kısa forma dönüştürülmüştür. Beden alanlarıyla alakalı 9, vücut ağırlığı ile alakalı 6 madde eklenmesiyle madde sayıs 69 olmuştur. Doğan ve Doğan tarafindan 1992 yılında ölçeğin geçerlilik ve güvenilirliği yapılmış ve ölçeğin kısa formunun Türkçe uyarlamas1 57 maddeden ve 7 alt gruptan oluşmaktadır. Psikolojik açıdan 3 yönden (duygusal, bilişsel, davranışsal), bedensel açıdan 3 (fiziksel görünüş, fiziksel yeterlilik, biyolojik bütünlük) göstergeden oluşan Çok Yönlü Beden-Self İlişkisi Ölçeği' nin 7 alt grubu mevcuttur. $\mathrm{Bu}$ alt boyutlar: Görünüşü Değerlendirme: 5, 9, 17, 23, 32, 40; Görünüş Yönelimi: 1, 2, 10, 18, 24, 25, 33, 34, 41, 42; Fiziksel Yeterliliği Değerlendirme: 3, 11, 19, 26, 35, 43; Fiziksel Yeterlilik Yönelimi: 4, 12, 13, 20, 27, 28, 36, 44, 45; Sağlık Değerlendirmesi: 6, 14, 21, 29, 37, 46; Sağl1k Yönelimi: 7, 8, 15, 16, 22, 30, 31, 38, 39, 47, 48; Beden Alanlarından Doyum: 49, 50, 51, $52,53,54,55,56,57$. Ters anlatıml maddelerin numaralar1; 12, 13, 14, 25, 26, 27, $29,30,31,33,35,37,39,40,41$ 'dir. Ters anlamlı maddeler ters kodlama yapilarak yeniden düzenlenmiştir. Beşli likert tipindeki ölçekte, her bir madde için en az 1 (kesinlikle katılmiyorum), en fazla 5 (kesinlikle kat1lyyorum) puan verilebilmektedir. Ölçek toplam puanı bir deneğin ölçekteki maddelerin tamamından almış olduğu toplam puanını gösterir. Ölçeğin Türkçe formunda bir deneğin ölçekten alabileceği puan en yüksek 285 en düşük ise $57^{\prime}$ dir. Bir deneğin bir alt grubun maddelerinden aldığ toplam puan, alt grup madde sayısina bölünmesiyle bulunur. Bulunan değer ayn 16 zamanda o alt grubun madde ortalama puanıdır. $\mathrm{Bu}$ durumda bir deneğin alt grup ortalama puanı en az 1, en fazla 5 olabilir. Pilates egzersiz program 1 TCF 'den pilates eğitimi almış alanında uzman antrenör eşliğinde 10 hafta süresince haftanın iki günü uyguland1, egzersizler 50 dakika yapılmıştır. Yapılan çalışmaya ilk ısınma egzersizleriyle başlanarak daha sonrasında pilates egzersiz serileri uygulanarak program tamamlanmıştır.

\section{Verilerin Analizi}

İstatistiksel analizler öncesinde yapılan normallik testi sınamasına göre dağılımın normal olduğu sonucuna ulaşılmıştır. Ölçeğin geneli ve alt boyutlar düzeyinde güvenilirlik analizi yapılmıştır. Çalışmada deney ve kontrol grubu karşılaştırmasında bağımsız örneklem t testi ve grupların kendi içlerinde karşılaştırmada ise eş örneklem $t$ testi kullanılmıştır. Bu çalışma da hata payı $\mathrm{p}<0,05$ olarak kabul edilmiştir.

\section{BULGULAR}

Araştırma kapsamında yararlanılan MBSRQ'nun ve alt boyutlarının çalışma başlangıcında araştırma örneklemi bağlamında uyumluluğunu tespit etmek için Cronbach Alpha değerleri incelenmiştir. Elde edilen sonuçlara göre; ölçeğin geneli için ve alt boyutlar düzeyinde Cronbach Alpha değeri 0,70'in üzerinde olup, bu durum ölçek güvenirliğinin iyi olarak kabul edilebilmesi için uygun olduğunu ve ölçeğin iç tutarl1lığa bağlı güvenirliğin sağlandığını göstermektedir (Tavşancıl 2014, Kozak 2017). Katılımcıların Çok Yönlü Beden-Self İlişkisi Ölçeği'ne ilişkin toplam skor ortalamaları $200.45 \pm 29.20$ 'dir. 
Tablo 1. Ölçek Alt Boyutları Güvenilirlik Analizi ve Toplam Skor Sonuçları

\begin{tabular}{lccc}
\hline Alt Boyutlar & Madde Sayıs1 & Cronbach Alpha $(\alpha)$ & Ortalama \pm SD \\
\hline Görünüşü Değerlendirme & 6 & 0,85 & $22,82 \pm 4,59$ \\
\hline Görünüş Yönelimi & 10 & 0,73 & $38,65 \pm 5,32$ \\
\hline Fiziksel Yeterliliği Değerlendirme & 6 & 0,70 & $20,98 \pm 4,24$ \\
\hline Fiziksel Yeterlilik Yönelimi & 9 & 0,85 & $25,56 \pm 7,44$ \\
\hline Sağlık Değerlendirmesi & 6 & 0,79 & $21,35 \pm 4,45$ \\
\hline Sağlık Yönelimi & 11 & 0,70 & $37,82 \pm 5,99$ \\
\hline Beden Alanlarından Doyum & 9 & 0.83 & $33,26 \pm 6,61$ \\
\hline MBSRQ & 57 & 0,92 & $200,45 \pm 29,20$ \\
\hline
\end{tabular}

Tablo 2. Katılımcıların Gruplarına Göre Ön Test Puanlarının Karşılaştırılması

\begin{tabular}{|c|c|c|c|c|c|c|}
\hline $\begin{array}{l}\text { Beden Alg1s1 Alt } \\
\text { Boyutlar1 }\end{array}$ & Gruplar & $\mathrm{N}$ & $\overline{\boldsymbol{X}}$ & Ss & $\mathrm{t}$ & $\mathrm{p}$ \\
\hline \multirow[t]{2}{*}{ Görünüş Değerlendirme } & $\mathrm{D}$ & 52 & 3,44 & 0,78 & \multirow{2}{*}{$-2,124$} & \multirow{2}{*}{$0,036^{*}$} \\
\hline & $\mathrm{K}$ & 52 & 3,78 & 0,84 & & \\
\hline \multirow[t]{2}{*}{ Görünüş Yönelimi } & $\mathrm{D}$ & 52 & 3,70 & 0,64 & \multirow{2}{*}{$-1,639$} & \multirow{2}{*}{0,104} \\
\hline & $\mathrm{K}$ & 52 & 3,88 & 0,47 & & \\
\hline \multirow{2}{*}{$\begin{array}{l}\text { Fiziksel Yeterliliğin } \\
\text { Değerlendirilmesi }\end{array}$} & $\mathrm{D}$ & 52 & 3,28 & 0,80 & \multirow{2}{*}{$-0,803$} & \multirow{2}{*}{0,424} \\
\hline & $\mathrm{K}$ & 52 & 3,39 & 0,52 & & \\
\hline \multirow{2}{*}{$\begin{array}{l}\text { Fiziksel Yeterlilik } \\
\text { Yönelimi }\end{array}$} & $\mathrm{D}$ & 52 & 2,74 & 0,82 & \multirow[b]{2}{*}{2,093} & \multirow{2}{*}{$0,039 *$} \\
\hline & $\mathrm{K}$ & 52 & 2,47 & 0,43 & & \\
\hline \multirow[t]{2}{*}{ Sağlık Değerlendirme } & $\mathrm{D}$ & 52 & 3,40 & 0,78 & \multirow{2}{*}{0,138} & \multirow{2}{*}{0,891} \\
\hline & $\mathrm{K}$ & 52 & 3,38 & 0,64 & & \\
\hline \multirow[b]{2}{*}{ Sağlık Yönelimi } & $\mathrm{D}$ & 52 & 3,23 & 0,59 & \multirow{2}{*}{$-1,255$} & \multirow{2}{*}{0,212} \\
\hline & $\mathrm{K}$ & 52 & 3,36 & 0,47 & & \\
\hline \multirow{2}{*}{$\begin{array}{l}\text { Beden Alanlarına } \\
\text { Doyum }\end{array}$} & $\mathrm{D}$ & 52 & 3,40 & 0,71 & \multirow{2}{*}{$-1,04$} & \multirow{2}{*}{0,301} \\
\hline & $\mathrm{K}$ & 52 & $3, .54$ & 0.65 & & \\
\hline \multirow[b]{2}{*}{ Toplam Puan } & $\mathrm{D}$ & 52 & $3, .31$ & 0.54 & \multirow{2}{*}{-0.899} & \multirow{2}{*}{0,371} \\
\hline & $\mathrm{K}$ & 52 & $3, .39$ & 0.36 & & \\
\hline
\end{tabular}

Tablo 2'de deney ve kontrol grubu katılımcilarının genel ve alt boyutlar bağlamında beden algıları ön test puanları; görünüş yönelimi, fiziksel yeterliliğin değerlendirilmesi, fiziksel yeterlilik yönelimi, sağlık değerlendirme, sağlık yönelimi, beden alanlarına doyum ve toplam skor açısından istatistiksel olarak anlamlı bir farklılık göstermemektedir ( $\mathrm{p}>0.05)$. Buna karşın, görünüş değerlendirme ve fiziksel yeterlilik yöneliminde ön test puanları bakımından deney ile kontrol grubu arasinda istatistiksel olarak anlamlı bir farklılık olduğu tespit edilmiştir $(p<0.05)$. Görünüş değerlendirme alt boyutunda kontrol grubu daha olumlu bir değerlendirmeye sahipken, fiziksel yeterlilik yöneliminde ise deney daha olumlu bir değerlendirmeye sahiptir. Elde edilen sonuçlar grupların çalışma başında birbirleri ile uyumlu dağılım gösterdiğine işaret etmektedir. 
Tablo 3. Katılımcıların Gruplarına Göre Son Test Puanlarının Karşılaştırılması

\begin{tabular}{|c|c|c|c|c|c|c|}
\hline Beden Alg1s1 Alt Boyutları & Gruplar & $\mathrm{N}$ & $\overline{\boldsymbol{X}}$ & Ss & $\mathrm{t}$ & $\mathrm{p}$ \\
\hline \multirow{2}{*}{ Görünüş Değerlendirme } & $\mathrm{D}$ & 52 & 4,37 & 0,58 & \multirow{2}{*}{7,12} & \multirow{2}{*}{$0,001 *$} \\
\hline & $\mathrm{K}$ & 52 & 3,62 & 0,49 & & \\
\hline \multirow{2}{*}{ Görünüş Yönelimi } & $\mathrm{D}$ & 52 & 3,92 & 0,54 & \multirow{2}{*}{$-0,401$} & \multirow{2}{*}{0,689} \\
\hline & $\mathrm{K}$ & 52 & 3,96 & $0, .43$ & & \\
\hline \multirow{2}{*}{$\begin{array}{l}\text { Fiziksel Yeterliliğin } \\
\text { Değerlendirilmesi }\end{array}$} & $\mathrm{D}$ & 52 & 4,13 & 0,61 & \multirow{2}{*}{9,13} & \multirow{2}{*}{$0,001 *$} \\
\hline & $\mathrm{K}$ & 52 & 3,19 & 0,43 & & \\
\hline \multirow{2}{*}{ Fiziksel Yeterlilik Yönelimi } & $\mathrm{D}$ & 52 & 3,85 & 0,49 & \multirow{2}{*}{17,45} & \multirow{2}{*}{$0,001 *$} \\
\hline & $\mathrm{K}$ & 52 & 2,30 & 0,42 & & \\
\hline \multirow{2}{*}{ Sağlık Değerlendirme } & $\mathrm{D}$ & 52 & 4,04 & 0,76 & \multirow{2}{*}{4,767} & \multirow{2}{*}{$0,001 *$} \\
\hline & $\mathrm{K}$ & 52 & 3,42 & 0,56 & & \\
\hline \multirow{2}{*}{ Sağlık Yönelimi } & $\mathrm{D}$ & 52 & 3,77 & 0,54 & \multirow{2}{*}{3,702} & \multirow{2}{*}{$0,001 *$} \\
\hline & $\mathrm{K}$ & 52 & 3,41 & 0,43 & & \\
\hline \multirow{2}{*}{ Beden Alanlarına Doyum } & $\mathrm{D}$ & 52 & 4,36 & 0,57 & \multirow{2}{*}{7,847} & \multirow{2}{*}{$0,001 *$} \\
\hline & $\mathrm{K}$ & 52 & 3,49 & 0,57 & & \\
\hline \multirow{2}{*}{ Toplam Puan } & $\mathrm{D}$ & 52 & 4,03 & 0,41 & \multirow{2}{*}{9,397} & \multirow{2}{*}{$0,001 *$} \\
\hline & $\mathrm{K}$ & 52 & 3.34 & 0,33 & & \\
\hline
\end{tabular}

$* \mathrm{p}<0.01$

Tablo 3'de kontrol ve deney kat1lımcilarının genel ve alt boyutlar bağlamında beden algıları son test puanları; görünüş değerlendirme, fiziksel yeterliliğin değerlendirilmesi, fiziksel yeterlilik yönelimi, sağl1k değerlendirme, sağlik yönelimi, beden alanlarına doyum ve toplam skor açısından istatistiksel olarak anlamlı bir farklıl1k göstermektedir $(\mathrm{p}<0.05)$. Belirtilen tüm alt boyutlarda ve genel skorda deney grubu katılımcılarının değerlendirmeleri kontrol grubu katılımcılarının değerlendirmesinden daha olumludur. Görünüş yönelimi son test skorları bakımından deney grubu ile kontrol grubu arasinda istatistiksel olarak anlamlı bir farklılık olmadığ 1 tespit edilmiştir $(\mathrm{p}>0.05)$. Her iki grubun görünüş yönelimi değerlendirme ortalaması birbirine yakın skora sahiptir.

Tablo 4. Deney Grubu Katılımcılarının Ön Test-Son Test Puanlarının Karşılaştırılması.

\begin{tabular}{lcccc}
\hline Beden Algısı Alt Boyutları & $\underline{\text { Ön Test }}$ & $\underline{\underline{\text { Son Test }}}$ & \multirow{2}{*}{$\mathrm{t}$} & $\mathrm{p}$ \\
\hline Görünüş Değerlendirme & Ort \pm Ss & Ort \pm Ss & & \\
\hline Görünüş Yönelimi & $3,44 \pm 0,77$ & $4,37 \pm 0,58$ & 2,739 & $0,001^{*}$ \\
\hline Fiziksel Yeterliliğin Değerlendirilmesi & $3,70 \pm 0,64$ & $3,92 \pm 0,54$ & 2,176 & $0,006^{*}$ \\
\hline Fiziksel Yeterlilik Yönelimi & $3,28 \pm 0,79$ & $4,13 \pm 0,61$ & 7,667 & $0,001^{*}$ \\
\hline Sağlı Değerlendirme & $2,73 \pm 0,82$ & $3,85 \pm 0,49$ & 5,399 & $0,001^{*}$ \\
\hline Sağlı Yönelimi & $3,40 \pm 0,78$ & $4,04 \pm 0,75$ & 4,81 & $0,001^{*}$ \\
\hline Beden Alanlarına Doyum & $3,22 \pm 0,59$ & $3,76 \pm 0,54$ & 4,721 & $0,001^{*}$ \\
\hline Toplam Puan & $3,39 \pm 0,71$ & $4,36 \pm 0,56$ & 1,582 & $0,001^{*}$ \\
\hline
\end{tabular}

$* \mathrm{p}<0.01$

Tablo 4'de görüldüğü üzere deney grubu katılımcılarının beden algısı ön test ve son test puanlar1; görünüş değerlendirme, görünüş yönelimi, fiziksel yeterliliğin değerlendirilmesi, fiziksel yeterlilik yönelimi, sağlık değerlendirme, sağlık yönelimi, beden 
alanlarında doyum ve toplam skor açısından istatistiksel olarak anlamlı bir farkl111k göstermektedir $(\mathrm{p}<0.05)$. Katılımcıların tüm alt boyutlarda ve toplam skorda son test puanları ön test puanlarından yüksektir.

Tablo 5. Kontrol Grubu Katılımcılarının Ön Test-Son Test Puanlarının Karşılaştırılması

\begin{tabular}{lcccc}
\hline Beden Algis1 Alt Boyutları & Ön Test & Son Test & $\mathrm{t}$ & $\mathrm{p}$ \\
\hline Görünüş Değerlendirme & Ort \pm SD & Ort \pm SD & & \\
\hline Görünüş Yönelimi & $3,77 \pm 0,83$ & $3,62 \pm 0,48$ & 2,739 & 0,103 \\
\hline Fiziksel Yeterliliğin Değerlendirilmesi & $3,88 \pm 0,47$ & $3,95 \pm 0,43$ & 2,176 & $0,002^{*}$ \\
\hline Fiziksel Yeterlilik Yönelimi & $3,38 \pm 0,52$ & $3,18 \pm 0,43$ & 7,667 & $0,001^{*}$ \\
\hline Sağlık Değerlendirme & $2,47 \pm 0,43$ & $2,30 \pm 0,42$ & 5,399 & $0,002^{*}$ \\
\hline Sağlı Yönelimi & $3,38 \pm 0,64$ & $3,41 \pm 0,56$ & 4,81 & 0,503 \\
\hline Beden Alanlarına Doyum & $3,35 \pm 0,47$ & $3,48 \pm 0,57$ & 4,721 & 0,163 \\
\hline Toplam Puan & $3,54 \pm 0,64$ & $3,48 \pm 0,57$ & 1,582 & 0,378 \\
\hline *p<0.01 & $3,39 \pm 0,36$ & $3,34 \pm 0,33$ & 5,092 & 0,169 \\
\hline
\end{tabular}

Tablo 5'de görüldüğü üzere kontrol grubu katılımcılarının beden algısı ön test ve son test puanları; görünüş yönelimi, fiziksel yeterliliğin değerlendirilmesi, fiziksel yeterlilik yönelimi açısından istatistiksel olarak anlamlı bir farklılık göstermektedir $(p<0.05)$. Görünüş yönelimi boyutunda son test puanları ön test puanlarından yüksek iken fiziksel yeterliliğin değerlendirilmesi ve fiziksel yeterlilik

\section{TARTIŞMA ve SONUÇ}

$\mathrm{Bu}$ çalışmada 10 haftalık süreçte uygulanan pilates egzersizlerinin beden algisina etkilerinin incelenmesi amaciyla uygulanan beden algisı ön test puanlar1 karşılaştırıldığında deney ve kontrol grubu katılımcilarının genel ve alt boyutlar bağlamında beden algıları ön test puanları; görünüş yönelimi, fiziksel yeterliliğin değerlendirilmesi, fiziksel yeterlilik yönelimi, sağlık değerlendirme, sağlik yönelimi, beden alanlarına doyum ve toplam skor açısından istatistiksel olarak anlaml 1 bir farkl1lık göstermemektedir $(\mathrm{p}>0.05)$. Buna karşın, görünüş değerlendirme ve fiziksel yeterlilik yöneliminde ön test puanları bakımından deney ile kontrol grubu arasinda istatistiksel olarak anlamlı bir farklılık olduğu tespit edilmiştir $(\mathrm{p}<0.05)$. Görünüş değerlendirme alt boyutunda kontrol grubu daha olumlu bir değerlendirmeye sahipken, fiziksel yeterlilik yöneliminde ise deney grubu daha olumlu bir yönelimi boyutlarında ise ön test puanları son test puanlarından yüksektir. Buna karşın görünüş değerlendirme, sağlik değerlendirme, sağlık yönelimi, beden alanlarına doyum ve toplam puan açısından kontrol grubu katılımcılarının ön test puanları ile son test puanları arasında istatistiksel olarak anlamlı bir farklılık bulunmamaktadır ( $\mathrm{p}>0.05$ ).

değerlendirmeye sahiptir. Bu durumun deney grubunun spora başlamaya karar vermesiyle aynı doğrultuda olduğu düşünülmektedir. Elde edilen sonuçlar grupların çalışma başında birbirleri ile uyumlu dağılım gösterdiğine işaret etmektedir.

Kontrol ve deney grubu katılımcilarının genel ve alt boyutlar bağlamında beden algıları son test puanlarının karşılaştırılması sonucunda; görünüş değerlendirme, fiziksel yeterliliğin değerlendirilmesi, fiziksel yeterlilik yönelimi, sağlık değerlendirme, sağlık yönelimi, beden alanlarına doyum ve toplam skor açısından istatistiksel olarak anlaml bir farkl111k göstermektedir $(p<0.05)$. Belirtilen tüm alt boyutlarda ve genel skorda deney grubu katılımcılarının değerlendirmeleri kontrol grubu katılımcılarının değerlendirmesinden daha olumludur.

Vergili (2012) yapmış olduğu çalışmada kalistenik-pilates egzersizlerinin fiziksel 
uygunluk ve yaşam kalitesi parametrelerini geliştirdiği sonucuna ulaşmıştır. Demir (2013) yaptığı çalışmada; yaşları 36 ve üstü 30 sedanter kadına 8 hafta boyunca haftada 3 gün pilates egzersizi uygulanmıştır. Çalışma sonucunda pilates egzersizlerinin fiziksel benlik alg1 düzeyine artış sağladığ gözlemlenmiştir. Her iki çalışmada bizim çalışmamızdaki pozitif gelişimi; deney grubu son test değerlerinin kontrol grubundan daha olumlu olmasinı destekler niteliktedir.

Araştırmaya katılan katılımcıların beden algıSı ön test ve son test puanlarının deney grubu bakımından karşılaştırılmasında; görünüş yönelimi, görünüş değerlendirme, fiziksel yeterlilik yönelimi, fiziksel yeterliliğin değerlendirilmesi, beden alanlarında doyum, sağlık yönelimi, sağl1k değerlendirme ve toplam puan açısından deney gurubu ön test ile son test puanları arasında istatistiksel olarak anlamlı bir farklılık olduğu tespit edilmiştir $(p<0.05)$. Tüm alt boyutlarda ve toplam skorda son test puanları ön test puanlarından yüksektir dolayısıyla çalışmamızda pilates egzersizleri beden algısı alt boyutlarının tümünü geliştirdiği sonucu gözlemlenmiştir.

Öztürk ve Bavlı'nın (2017) yapmış oldukları çalışmada sedanter kadınların katıldığı 8 haftalık step-aerobik ve pilates egzersizlerinin benzer sonuçlar gösterdiği psikolojik değişkenleri olumlu etkilediği araştırma sonucunun çalışmamızla benzer özellik gösterdiği görülmektedir.

Vaquero-Cristóbal ve ark. (2021) yaptıkları çalışma sonucunda düzenli mat pilates veya reformer pilates yapan kadınların beden imajının iyileşerek beden memnuniyetsizliğinin azalacağını belirtmişlerdir.

Deneklerin görünüş yönelimi, görünüş değerlendirme, fiziksel yeterlilik yönelimi, fiziksel yeterliliğin değerlendirilmesi, beden alanlarına doyum, sağlık yönelimi, sağlık değerlendirme ve toplam puan açısından deney gurubu ön test ve son test puanlarinın karşılaştırılmasında deney grubu katılımcılarının tüm alt boyutlarda ve toplam skorda son test puanları ön test puanlarından daha yüksek olduğu tespit edilmiştir.
Er (2015) yaptığı çalışmada aerobik antrenmanın beden alg1s1 üzerine etkisini incelemiş ve kadınların yapmış oldukları egzersizlerin onların sağlık, görünüm, bedensel anlamda doyum yaşamalarına ve fiziksel yeterlilik algısına katkı sağladığını ve böylece beden algisı üzerine olumlu etki yaptığını belirtmiştir.

Işık (2020) yaptığı çalışmada obez kadınlara haftanın 3 günü 8 haftalık süre boyunca dans terapi egzersizleri uygulanmış ve bu egzersizlerin deney grubunun beden algisinı yükselttiği, yaşam kalitesini arttırdığı, yorgunluk ve depresyon seviyesini düşürdügünü gözlemlemiştir. Araştırmac1 egzersizin sadece bireysel sağlık için değil aynı zamanda toplum sağlığı için önemine dikkat çekmiştir.

Akman (2019)'ın yapmış olduğu çalışmada; fazla kilolu ve obez bireylerde beden algisı, benlik saygısı ve algılanan sosyal desteğin yaşam doyumuyla ilişkisi incelenmiş olup, yapılan çalışma sonucunda fazla kilolu ve obez bireylerde benlik saygisı ve beden algısının yaşam doyumu düzeyinde önemli bir etkisi olduğu ve benlik saygısı ile beden algıs1 arttıkça yaşam doyumunun da arttığı tespit edilmiştir.

Sporun beden alg1 düzeyini artırdığını gösteren bir başka çalışma da ise Alagül (2004) yaptığı araştırma da sporcuların spor yaşantılarında deneyimleri arttıkça beden algılarının yükseldiği belirtilmiştir. Kim ve Sul (2021) çalışmalarında pilates ve yoga birleşim egzersizlerinin düzenli uygulanmasının kas kütlesi, bazal metabolizma ve beden doyumu üzerine olumlu etkileri olduğu sonucunu bulmuştur.

Yaşları 18-50 arasında değişen fiziksel engelli spor yapan ve spor yapmayan bireylerin incelendiği bir çalışmada spor yapan engelli bireylerin spor yapmayanlara göre daha yüksek beden algısana sahip oldukları, yaşam doyumunun daha yüksek ve stres, anksiyete gibi psikolojik problemlerin daha düşük seviyede olduğu belirlenmiş̧tir (İldem2019).

Literatürdeki çalışmalar incelendiğinde yapmış olduğumuz çalışma ile diğer araştırmaların benzer sonuçlar gösterdiği ve egzersizin kişide beden algısında olumlu 
yönde bir etki sağladığı görülmekte olup, egzersiz ve fiziksel etkinliği hayatın içerisine yaymanın sedanter bireyleri zihinsel ve bedensel anlamda korumaya alabilmenin en yararlı yöntemlerinden biri olduğu görülmektedir.

Sonuç olarak yaptığımız bu çalışmada pilates egzersizlerinin beden algısını pozitif etkilediği görülmektedir. Çalışmada deney grubundaki kadınların yapmış oldukları pilates egzersizlerinin bireylerin görünüşlerini, sağlıklarını, fiziksel uygunluklarını beden alanlarında doyuma ulaşmalarını ve fiziksel yeterlilik algısını olumlu etkilediği sonucu görülmektedir. Artan beden algisı bireylerin kendilerini mutlu, kıymetli ve daha güvende hissetmesini sağlamaktadır. $\mathrm{Bu}$ çalışma sonuçları spor referans alınarak; 10 hafta ve üzeri reformer ve mat egzersiz programlarının kadın ve erkeklerde beden algisına etkisi incelenebilir

\section{Yazarların Makaleye Katkı Beyanı}

Makale tasarımı; Adem Civan, Hediye Küçükkapan; Literatür taraması: Adem Civan, Hediye Küçükkapan; Makale yazımı: Adem Civan, Hediye Küçükkapan; Dergi yazım kurallarına uygun şekilde düzenlenerek gönderilmesi: Adem Civan.

\section{Çıkar Çatışması}

Yazarların beyan edecek herhangi bir çıkar çatışmasi yoktur.

\section{Finansal Destek}

Bu çalışmanın yapılabilmesi için herhangi bir finansal destek alınmamıştır.

\section{Etik Kurul Onayı}

$\mathrm{Bu}$ çalışma Helsinki bildirgesi ile uyumludur. Selçuk Ünversitesi Spor Bilimleri Fakültesi Girişimsel olmayan klinik araştırmaları etik kurulundan (27/12/2019-83) onaylıdır.

\section{Hakem Değerlendirmesi}

Kör hakemlik süreci sonrası yayınlanmaya uygun bulunmuş ve kabul edilmiştir.

\section{KAYNAKÇA}

Akman, G. (2019). Fazla kilolu ve obez bireylerde beden algisl, benlik saygisl ve algllanan sosyal desteğin yaşam doyumuyla ilişkisinin incelenmesi. Yüksek Lisans Tezi, Maltepe Üniversitesi Sosyal Bilimler Enstitüsü, İstanbul.

Alagül, Ö. (2004). Farklı spor branşlarında ki sporcuların atılganlık ile beden algisı ilişkisi. Yüksek Lisans Tezi, Ege Üniversitesi Sağlık Bilimleri Enstitüsü, İzmir.

Civan A.H. (2021). Fiziksel aktivite ve spor. Spor Bilimleri II. Editör Z.F. Dinç. Akademisyen Kitabevi, Ankara, 33-45.

Cruz-Ferreira, A., Fernandes, J., Laranjo, L., Bernardo, L.M., Silva, A. (2011). A systematic review of the effects of pilates method of exercise in healthy people. Archives of Physical Medicine and Rehabilitation, 92, 2071-2081.

Cusumano, D.L., Thompson, J.K. (1997). Body imageand body shapeideals in magazines: exposure, awareness, andinternalization. SexRoles, 37, 701-721.

Demir, T.Y. (2013). Orta yaş sedanter bayanlarda pilates egzersizlerinin fiziksel özellikler ve vücut imajına etkisinin araştırılmast. Yüksek Lisans Tezi. Süleyman Demirel Üniversitesi Sağlık Bilimleri Enstitüsü, Isparta.

Er, Y. (2015). Aerobik antrenmanların beden algısı üzerine etkisi. Yüksek Lisans Tezi, Selçuk Üniversitesi Sağllk Bilimleri Enstitüsü, Konya.

Ergun, Ö. (2017) Sosyal latin danslarının beden algısl, öz-yeterlik ve sosyal beceri üzerine etkisinin incelenmesi. Yüksek LisansTezi, Celal Bayar Üniversitesi, Sosyal Bilimler Enstitüsü, Manisa.

Işık, T. (2020). Obez kadınlarda dansterapinin yaşam kalitesi, yorgunluk, beden algisı ve depresyona etkisi. Yüksek Lisans Tezi, Hasan Kalyoncu Üniversitesi Sağlık Bilimleri Enstitüsü, Gaziantep.

İldem, E. (2019). Sporcu ve sporcu olmayan fiziksel engele sahip bireylerin psikolojik dayanıklılık, beden algısı ve psikolojik iyi olma durumu. Yüksek Lisans Tezi, Bahçeşehir Üniversitesi Sosyal Bilimler Enstitüsü, İstanbul. 
Kim, SH., Sul, J.K. (2021). Effect of pilates · yoga complex treatment on body 1mage, muscle mass and basal metabolism in female college student. Annals of the Romanian Society for Cell Biology, 25, 811-817.

Kloubec, J.A. (2010). Pilates for improvement of muscle endurance, flexibility, balance, and posture. The Journal of Strength \& Conditioning Research, 24(3), 661-667.

Kozak, M. (2017). Bilimsel Araştırma: Tasarım, Yazım ve Yayım Teknikleri. 3. Basım, Detay Yayıncılık: Ankara.

Morrison, T.G., Kalin, R., Morrison, M.A. (2004). Body-image evaluation and body-image investment among adolescents: a test of sociocultural and social comparison theories. Adolescence, 39, 571-87.

Nieman, D.C. (2007) Exercise Testing And Preseription A Healty-Related. Appalachian State University. p. 47-77, 123-237.

Öztürk, F., Bavlı, B. (2017). Investigation of the effects of eight weeks of pilates and stepaerobic exercises on physical performance and self esteem scores of females. International Journal of Science Culture and Sport, 5, 76-86.

Şavkın, R. (2014). Pilates eğitiminin vücut kompozisyonuna etkisi. Yüksek Lisans Tezi, Pamukkale Üniversitesi Sağlık Bilimleri Enstitüsü, Denizli.

Tavsancil, E. (2014). Tutumların ölçülmesi ve SPSS ile veri analizi. Nobel Yayıncılık, Ankara.

Uslu, D. (2019). Bedeni beğenme-sosyal yetkinlik arasındaki ilişkilerin çeşitli değişkenler açısından incelenmesi. Yüksek Lisans Tezi, İstanbul Gelişim Üniversitesi Sosyal Bilimler Enstitüsü, İstanbul.

Vaquero-Cristóbal, R., López-Miñarro, P.Á., Alacid, F., González-Gálvez, N., EsparzaRos F. (2021). Evolution of body image perception and distorsion with mat and apparatus pilates practice in adult women. Nutricion Hospitalaria, 38, 161-168.

Vergili, Ö. (2012). Sağllklı sedanter kadınlarda kalistenik ve pilates egzersizlerinin sağlıkla iliş̧kili yaşam kalitesi üzerindeki etkileri. KÜ Tıp Fakültesi Dergisi, 14, 1302-1314.
Yararbaş M. (2013). Orta yaş kadınlarda 8 hafta uygulanan pilates egzersizlerinin antropometrik özelliklerine ve beden algısına etkilerinin araştırılması. Yüksek Lisans Tezi Süleyman Demirel Üniversitesi, Sağlık Bilimleri Enstitüsü, Isparta 